УДК 821.163.41.09

https://doi.org/10.18485/godisnjak.2017.12.8

Ненад В. Николић*

Универзитет у Београду

Филолошки факултет
Оригинални научни рад

Примљен: 6. 10. 2017.

Прихваћен: 23. 10. 2017.

\title{
ПАВЛЕ ПОПОВИЋ О ДОСИТЕЈУ ОБРАДОВИЋУ
}

\begin{abstract}
У раду се анализирају чланци и студије Павла Поповића посвећени делу Доситеја Обрадовића. У њима се препознаје неколико различитих идеолошких и методолошких опредељења: младалачка осуда Доситеја Обрадовића због критике манастира, истицање Доситеја као зачетника нове српске књижевности и још увек актуелног писца, те темељно компаративно проучавање Собранија разних нравоучителних вешчеј и Мезимия. Ова опредељења посматрају се у контексту Поповићевих општијих методолошких, књижевноисторијских и политичких ставова.
\end{abstract}

Кључне речи: Мезимаи, Доситеј Обрадовић, Павле Поповић, Собраније разних нравоучителних вештеј

Доситеј Обрадовић био је тема Павла Поповића током целог његовог научног века. Први осврт на Доситеја учинио је 1894. године у свом раном програмском тексту „Критика у српској књижевности”, док је последњу, дуго рађену студију „О Собранију [разних нравоучителних вешчеј, в ползу и увеселеније, 1793] Доситеја Обрадовића" објавио 1938, годину дана пред смрт, а затим је у години своје смрти допунио анализом Мезимияа. Част втора Собранија разних нравоучителних вешчеј, в ползу и увеселеније (1818, постхумно). Та студија Поповићев је најобимнији рад о Доситеју, читава монографија, која обимом вишеструко премашује све остало што је о Доситеју написао заједно узето. Такође, у тој студији-монографији први пут се у истом тексту налазе две тежње које су претходне четири

\footnotetext{
* Филолошки факултет Универзитета у Београду, Студентски трг 3, 11000 Београд, Србија.
} 
деценије управљале писањем чланака о Доситеју, који су били или опште оцене Доситејевог дела или компаративне анализе без ширег контекста. У студији-монографији о Собранију... ове две тенденције су комбиноване (Поповић 1938-39: 74), мада не и заиста интегрисане. Још интересантније - када је реч о целини Поповићевог погледа на Доситеја - јесте да он није увек био исти и безрезервно позитиван, премда је Поповић настојао да остави утисак да је баш тако било.

Завршавајући свој последњи пригодни чланак о Доситеју - поводом сто педесете годишњице његове прве књиге - Павле Поповић је са више понетости и отуда мање тачности него икада пре истакао да „Доситије је изазвао читаву револуцију у књижевности. Он је творац српске модерне књижевности [...] Он је дао тон целом једном веку [...] Цела једна нова књижевност родила се на једанпут, држећи се програма који јој је он прописао” (Поповић 1934: 188). Потом је пребацио омладини да „греши што не чита Доситија довољно. Он је у свима својим главним књигама и данас добар и сувремен" (Поповић 1934: 188). На крају, чланак је завршио личном жељом - „Ја бих волео да наша омладина заволи Доситија онако како га ја волим и како он доиста заслужује" (Поповић 1934: 189) - и признањем да „овај ми је писац од младости мио, и ја сам рад да се он многима од нашег младог света омили" (Поповић 1934: 189). Писан не само да донесе општу оцену већ и очигледно пропагандистичког тона, тај чланак није разликовао оно што монографија о Собранију... (чији је први део Поповић изложио на седници Академије годину дана раније) јесте разликовала: у њој је Поповић на питање „колико ти чланци [из Собранија...] вреде данас” експлицитно одговорио: „на жалост, не много” (Поповић 1938-39: 77). Потом је вредност Собранија... потражио у другим његовим аспектима. Међутим, поред тога што се у изношењу опште оцене Доситејевих вредности у пригодном чланку није водио сопственим вредносним критеријумом примењиваним у научним студијама, Поповић је нетачно представио и оно што је у том излагању било најличније - сопствено искуство наведено као мотив за популаризацију Доситеја међу омладином. Јер, Поповићу Доситеј није био „од младости мио”: у свом првом програмском чланку „Критика у српској књижевности”, писаном тачно четири деценије раније, Поповић је био врло оштар тврдећи да се „и великим духовима као што је био Доситије, могао десити случај да у ватреној ревности за пропагирањем својих идеја, забораве да гледају умесност развијених идеја према средини у којој су те идеје ширене [...] Доситије је био толико занет космополитским идејама 18. века да није могао да опази неумесност њихову у питањима у којима је националност 
требало да води прву реч, а српски читаоци, зато што су имали велико поштовање према њему нису могли да заштите интересе српске од бујне критике његове иако је национална тежња српска могла то захтевати од њих" (Поповић 1894: 180-181).

Разлика је, дакле, толика да сваки став из 1934. представља потпуну супротност ставу из 1894: ако је крајем деветнаестог века за Поповића Доситеј пропагирао идеје неумесне у српској култури, која је њиховим прихватањем учинила штету не само својим књижевним и културним, већ и националним интересима, како је дошло до тога да тридесетих година двадесетог века Доситеј буде слављен као творац модерне српске књижевности и неко чија актуелност још увек није прошла, иако је Поповић, говорећи као научник, знао да Доситеј није више на тај начин актуелан? Не дугује ли та претераност у похвали не само пропагандистичком тону пригодног чланка поводом стопедесетогодишњице Доситејеве прве књиге, већ и неком дубљем психолошком механизму, објављеном у Поповићевој тврдњи да му је Доситеј „од младости мио”? С обзиром да то уопште није било неопходно саопштити ни у пропагандистички интонираном чланку, та реченица, својом непотребношћу и стога очигледном нужношћу да буде изречена, могла би упутити на механизам опорицања, на Поповићеву тежњу да претеривањем у похвалама потисне своју некадашњу осуду Доситеја, јер „опорећи нешто расуђивањем, у основи значи: то је нешто што бих најрадије желео да потиснем" (Freud 1925: 113). Али, иако „просуђивање је интелектуална замена за потискивање” (Freud 1925: 113), Поповић своју промену мишљења никада није образложио, нити је икада - а четрдесет четири године је прошло између „Критике у српској књижевности" и монографије о Собранију... - о адекватности Доситејевих идеја српском друштву осамнаестог века расуђивао на нијансиранији начин, рецимо онако како ће то касније учинити Мита Костић (1952)? Поповић је о Доситејевим идејама без изузетка говорио као о превратничким и револуционарним, али их је различито вредновао - крајем деветнаестог века негативно, потом позитивно. Ни у једном случају то вредновање није поткрепио развијенијим тумачењем у ширем контексту српске културе осамнаестог века, иако је очигледно да је оно проистекло управо из начина на који је Поповић ту културу схватао: „Ви знате да је Доситије, понесен оном струјом слободоумних идеја која је апсорбовала целу Европу 18. века, нападао на манастире уопште, а ви знате колика је била важност манастира за културу српског света, и закључујете да ако су манастири збиља били, у очима мислилаца 18. века, једна штетна установа, да су српски манастири могли ипак бити врло корисна установа за националност српску” (Поповић 1894: 180). 
Очекивано, у чланку из 1934. сасвим је другачији поглед не само на Доситеја, већ и на значај српских манастира. Иако је већ у предавању „Доситеј Обрадовић у Енглеској”, одржаном у Лондону 1918. за енглеску публику, за Хопово укратко казао да „калуђери који су ту живели били су све, само не свеци, и једино један дечко са јако развијеном маштом могао је бити толико слеп да у тим бедним створовима гледа свој идеал" (Поповић 1919: 46), ипак је у чланку из 1934. - објављеном, иронично, у Календару Св. Саве - оцена манастира била најсуровија: Доситеј у Хопову „живљаше као да је у Средњем Веку, а међутим је живео усред просвећеног осамнаестог века. Чудна слика примитивности у којој се тада налазио наш народ!” (Поповић 1934: 186). Тако је Поповић од манастира који су у осамнаестом веку могли бити корисна установа за српску националност стигао до истих тих манастира као знака примитивности српског народа. Та супротност исувише је радикална да би се могла назвати икако другачије него обртом у Поповићевом разумевању српске културе, али његови текстови посвећени Доситеју дају мало могућности да се тај обрт објасни - колико је јасно видљиво место на којем је до њега дошло, толико су у тами његови разлози. ${ }^{1}$

Ипак, једно је, поред радикалне промене мишљења, сасвим очигледно: шта год мислио о манастирима, Поповић оно што у неком тренутку мисли, нити шире образлаже нити у то своје мишљење и за тренутак сумња. Реторика „Критике у српској књижевности” сугестивним обраћањем читаоцима („ви знате”) стварала је утисак да се пред њих излаже аксиом на основу којег треба осудити неадекватност Доситејевих идеја, док ће у каснијим чланцима опорицањем кроз претерану похвалу Поповић потискивати своју ранију критику Доситеја и нигде неће допустити ни најмањи наговештај да су манастири ипак могли барем нечему служити. Макар не православни.

Јер, у такође пригодном говору, одржаном 1926. поводом седамстогодишњице св. Фрање Асишког, Поповић не само што је тврдио да су књиге фрањеваца „припремале пут [...] Доситеју и Вуку” (Поповић 1927: 143), што је необично с обзиром да почетком века Поповић није допу-

${ }^{1}$ Разлог не би могло бити ни упознавање са документима које је Тихомир Остојић представио у монографији Доситеј Обрадовић у Хопову (1907), јер је до обрта - као што ће се видети - дошло пре ње. Узгред, ову Остојићеву монографију Поповић није нарочито ценио: пишући о архивском раду и нужном избору грађе која ће бити унета у студију на основу ње писану, приметио је да „неки то не чине; што год су нашли у архиву, они сматрају да треба да унесу у своју расправу, у текст или примедбу; некад отварају сасвим непотребне главе у расправи само да би могли унети све; карактеристичан пример: Тихомир Остојић са књигом о Доситију у Хопову” (Поповић 1932: 130). 
штао да постоји битна веза ни између значајније дубровачке књижевности и Доситеја и Вука. ${ }^{2}$ Очигледно вођен југословенском идејом чији је био изразити промотер, Поповић је фрањевце и Доситеја (као и Вука, Симу Милутиновића Сарајлију и Лукијана Мушицког), употребио као елемент у изградњи јединствене књижевности јединственог народа. Значи ли то да Поповић није био против манастира у начелу, него да је његова осуда манастира првенствено била усмерена на српске манастире и њихову улогу у српској култури, која је била онемогућавајућа по тражено југословенско, а пре тога илирско јединство?

Међутим, и ако се позиција из које се српски манастири виде као знак примитивности српског народа, а фрањевачки манастири уздижу као важни за српску културу препознаје као одређена југословенском политиком, она не може објаснити обрт у Поповићевом мишљењу о Доситеју и манастирима, јер је до њега дошло пре Поповићевог окретања југословенству. Ипак, оно може бити важно као знак да критика манастира не потиче из универзалне позищије - онакве какву су заступали Доситеј и осамнаести век уопште - него да је чврсто везана за српску културу. У тренутку када буде стао на југословенско становиште, Поповић ће предратну критику српских православних манастира наставити у име југословенства због којег ће хвалити фрањевачке манастире, али - у име чега је та критика започела, после младалачке уверености да су ти манастири могли бити корисни по српску националност? У каквој је она вези са мењањем схватања Доситејеве улоге у српској култури? Шта је старије: промена суда о манастирима или Доситеју?

Чланак „Једна погрешка Доситијева” из 1897. био је управо у знаку потребе да се симпатије за Доситеја помире са критиком његових идеја, и то баш оних које су биле против манастира. Чланак се већ својим првим пасусом директно надовезао на Поповићеву три године ранију критику Доситеја и његовог односа према манастирима: „Доситије је, кажу, учинио једну погрешку, за коју му ми данас замерамо. Он је, наиме, нападао на манастире као на штетну установу а они, међутим, нису били штетни него су, напротив, у нашој прошлости чинили огромне услуге народности нашој. Ипак зато ми не треба много да му замерамо јер је он ову погрешку доцније признао. Он, до душе, то није нигде изреком рекао, али има

2 „За Доситија, даље, [Матија Бан] каже да се у његову 'језику и саставу осјећа уплив списатеља дубровачких' а за Вука овако говори: 'али онај који је више него ико учио језик класичника дубровачких и по њима писао јест Вук Стефановић из Србије...' Ми бисмо највише волели да је то тако било, и да је тако јака веза између дубровачке и новије књижевности, али је ствар далеко од тога" (Поповић 1903: 440). 
околности по којима се то даје закључити” (Поповић 1897: 405). Поповић je, дакле, покушао да своју критику не само ублажи, већ и да Доситеја делимично рехабилитује: не његове идеје против манастира - које су за Поповића и даље „погрешка" - већ Доситеја као човека који се због тих идеја покајао. То је учинио у два корака: најпре делимичним ограђивањем од своје критике која је гађала Доситеја у целини, представљајући је као излагање општеприхваћених ставова („Доситије је, кажу, учинио једну погрешку"), а потом интерпретацијом онога што би било Доситејево „доцније признање” грешке. Та интерпретација није сасвим уверљива: „Претпоследња и последња глава [Мезимиа] тесно су везане. Доситије је бацио један летимичан поглед на улогу коју је имао и, налазећи и да је одиста требало борити се за напредне идеје као што је он то учинио, написао је 17. главу своје књиге. Затим је посумњао у потпуну тачност идеја за које се борио, опазио да су оне у нечем могле бити погрешне и штетне и написао 18. главу. У једној је назначио корист свога рада, у другој се правдао ако је својим радом утицао у нечем штетно" (Поповић 1897: 406). Међутим, баш својом неуверљивошћу - јер Доситеј се на тим местима не осврће на значај манастира и свој однос према њима - та интерпретација је важна: као сведочанство да је Поповићу било изузетно стало да своје мишљење о Доситеју из „Критике у српској књижевности” коригује: „Ако је он, дакле, учинио погрешку, он ју је признао. Немојмо му дакле замерати него поштујмо његову храброст и његову искреност" (Поповић 1897: 406). Међутим, коригована је само представа о Доситејевој личности - храброј и искреној - док су његове идеје о манастирима и даље сматране погрешним. То значи да промена у схватању значаја манастира није ишла паралелно са променом у схватању Доситејеве личности. Зато би се и могло поставити питање није ли преко рехабилитације Доситејеве личности Поповић временом усвојио и његове идеје, па и критику манастира?

Несумњиво је следеће: Поповић је 1894. критиковао Доситеја због његовог става према манастирима, 1897. је Доситејеву личност рехабилитовао задржавајући критику његових схватања о манастирима, да би у приступном предавању „Проучавање српске књижевности, његови правци и методи” 1904. за Доситеја рекао да је „у себи прибрао све што је трезвена књижевност XVIII века могла дати једном мудром, благородном и вредном човеку, а који је своме народу давао само оне идеје које је он, по свом дубоком познавању тога народа, сматрао као најпрече и најближе" (Поповић 1904: 13). Ово последње је оцена од које Поповић више никада неће одустати. Обрт у његовом погледу на Доситеја десио се, дакле, током једне деценије: од 1894. до 1904. потпуно је преокренут начин на који је 
Поповић посматрао Доситеја, а који је био праћен и промењеним погледом на улогу манастира у српском друштву осамнаестог века. Те две промене истог смисла ишле су упоредо, али не паралелно и истовремено, јер је рехабилитација Доситеја почела пре осуде манастира. Зато је и тешко рећи, посматрајући само Поповићеве текстове о Доситеју, шта је условило обрт у његовом мишљењу. Да ли је то био притисак културе у којој је Доситеј био високо цењен? Такав притисак, ако је он био заслужан за обрт, морао је бити праћен Поповићевом унутрашњом променом односа према Доситеју, толико снажном и далекосежном да ће још једну деценију касније, у свом личном дневнику, писаном за време Првог светског рата, започетог мотом "In Christi nomine Amen", забележити да планира „хаџилук по Доситејеву Лондону” (Поповић 2001: 361), односно да је ишао „за Доситејем: Clement's Lane, Hermitage” (Поповић 2001: 626). То су били изрази Поповићевог најинтимнијег осећања блискости са Доситејем. Отуда, ако је култура утицала на промену Поповићевог става, она је то учинила дубински мењајући његово разумевање Доситеја, а што је било могуће јер је пала на плодно тло претходне Поповићеве симпатије за његову личност. Са те стране може се објаснити и Поповићево опорицање те сопствене младалачке критике: сувишност тврдње да му је Доситеј био „од младости мио” оспољава најинтимнију драматичност Поповићевог односа према Доситеју.

Та драматичност, међутим, осим на Поповићеву психологију, упућује и на нешто што има књижевноисторијски значај, и то не само за Поповићево схватање Доситеја, већ за његову књижевну историју уопште: Поповићево расуђивање засновано је на претпоставкама које се не испитују, односно аксиомима. Ни када је најпре давао предност манастирима, нити потом стајући уз Доситеја против њих, ${ }^{3}$ Поповић ни у једном тренутку није покушао да вишестрано испита значај српских манастира у осамнаестом веку и адекватност Доситејеве критике. Аксиоматичност Поповићевог приступа је, разумљиво, најуочљивија у кратким, пригодним чланцима, али је и студија-монографија о Собранију... базирана на аксиомима; занимљиво, понекада се у кратким чланцима могу препознати поједине аналитичке идеје које, међутим, ни у студији-монографији о Собранију... неће бити развијене.

\footnotetext{
${ }^{3}$ Вреди још једном напоменути да је са прихватањем југословенске идеје као средишње у свом раду Поповић напустио универзалност Доситејеве критике манастира, те су за њега српски манастири остали израз српске „примитивности” (Поповић 1934: 186), док је у деловању фрањеваца препознавао „идеје толеранције и љубави” (Поповић 1927: 146).
} 
Говорећи у свом приступном предавању „Проучавање српске књижевности, његови правци и методи" о значају компаративних студија, Павле Поповић је као пример узео Доситеја: „Како бисмо јасну слику имали нпр. о Доситију кад бисмо похватали све изворе из којих је црпао, или све узоре за којима је ишао састављајући своја дела!" (Поповић 1904: 23). Упоредо са испитивањем извора - од 1911. и кратког прилога „Доситеј и Лабријер” који ће „саопштити извор само једног пасажа из Собранија” (Поповић 1911: 37) до предсмртне студије-монографије о Собранију... у којој су испитани извори свих прилога у њему - Поповић је без задршке износио врло јасне и одсечне оцене о Доситеју, у кратким и по правилу пригодним чланцима: при откривању споменика, да Енглезима пред крај Првог свестког рата приближи Србе, поводом сто педесете годишњице прве Доситејеве књиге. Какав је, онда, однос опште оцене и компаративних истраживања? Она не може из њих бити изведена јер то жељено идеално знање о изворима Поповић никада није постигао (јесте само о Собранију..., а и то тек пред крај живота), што значи да је општа оцена била изведена из неексплициране рефлексије на основу читања Доситејевих дела (о највећем броју њих Поповић никада није детаљније писао) и утицаја традиције тумачења и културе. Обратно, како традиција и култура утичу на правац поредбеног испитивања, види се у првом компративном, кратком чланку „Доситеј и Лабријер”: Поповић је, утврдивши један Доситејев извор, желео - „не задржавајући се на начину како је Доситеј преводио” (а чиме ће се касније бавити) - „само рећи да ово место Доситејева Coбранија врло високо карактерише образованост Доситијеву. Ми смо знали да је Доситије читао врло ваљане писце; нисмо мислили да ће читати и Лабријера, који је не само висок дух, него и један од оних који нису врло популарни и чија је лектира припадала само добро образованим људима; Лабријер је, на пример, и данас врло мало познат у нас и непреведен [...] Околност да је Доситије читао и преводио Лабријера у доба Карађорђево у Србији, даје тому преводу и читању још више важности" (Поповић 1911: 39). Очигледно, Доситејева вредност није оцењена с обзиром на квалитет његовог превода, вредност самог преведеног чланка, његову функционалност у склопу Собранија..., већ само с обзиром на чињеницу да је Лабријер елитистички писац и да његово познавање сведочи о Доситејевој култури која је далеко одскакала над културом доба и средине у којима се налазио.

Међутим, само три године касније, дајући општу оцену Доситејеву приликом откривања његовог споменика, Павле Поповић је Доситејеву вредност темељио на нечему другоме. Пошто је истакао да он има „пуно неоспорних заслуга" (Поповић 1914: 40), Поповић је пред његовим споме- 
ником показао зашто он „увек остаје одличан писац, првокласни стилист, узор и магистар у тешкој уметности писања" (Поповић 1914: 40), детаљно - детаљно с обзиром на прилику, разуме се - анализирајући Доситејев стил. Док је у компаративном истраживању Доситеја био високо вредновао јер је добацио до читања и превођења најелитнијих писаца, стилистичка анализа пажњу је усмеравала на оно што је најизворније Доситејево и што је, пре свега, најнепосредније литерарно у његовом делу. Отуда је ово била права књижевна оцена, док је претходна, компаративна, била више везана за стање српске културе и Доситеја у њој.

Управо је усмереношћу на литерарност Доситејевог дела - пресудну и за његов просветитељски карактер, јер Доситејев „главни циљ био је да шири своје просветне идеје; ни издалека их он не би могао тако раширити да није владао тајнама лепога писања" (Поповић 1914: 41) - Поповић објашњавао због чега је Собраније..., које „не ужива много ни симпатије у нас" (Поповић 1938-39: 69) и о чијој вредности у традицији тумачења „мишљење је веома неповољно” (Поповић 1938-39: 69), за њега било ,jедно од најбољих и најпријатнијих дела Доситејевих [...] има чланака који су, у најмању руку, исте вредности као и они у Советима или као они који чине коментар Баснама [...] По моме укусу, да није написао Собраније, Доситије би имао далеко мање дражи и привлачности него што их има са овим делом" (Поповић 1938-39: 70). Поповић је, тако, на крају свог бављења Доситејем, у најтемељнијој студији-монографији коју му је посветио, разликовао Доситејева дела по ьиховим идејама - „Сад у Собранију, он је старији, или стар, свакако потпуно зрео; пун је искуства и знања; миран је и сталожен; није га више брига за калуђере (доста се бавио њима); неће више да руши него да зида; ако је и даље за реформе, он је некако полако за њих; он сад хоће да да нешто позитивно, да покаже шта је то права мудрост, какав је онај високи свет идеја и науке ради којих је некада чинио непоштедну критику" (Поповић 1938-39: 71) -, али и стилу: „Нема, или бар има врло мало, оне сувишне фамилијарности која је у Советима или коментарима Басана" (Поповић 1938-39: 71) и „тон је доиста промењен” (Поповић 1938-39: 72). Управо је то тон који је Поповић ценио и због чега Доситеј за њега без Собранија... „не би био оно што јесте, његова фигура изгубила би много од свог значаја" (Поповић 1938-39: 73), што значи да је Поповић нарочиту пажњу посветио Собранију... јер је у њему препознавао најбољи Доситејев стил, што му је затим пружило могућност да Доситејев опус види на другачији начин него што је било уобичајено у традицији тумачења.

Отуда, Поповићев почетни импулс писања о Собранију... био је полемички. Међутим, после уводног навођења ставова из традиције тума- 
чења са којима се није слагао, Поповић више са њима није расправљао. Такође, иако је као оно најзначајније у Доситејевом делу видео његов стил - као пресудни фактор литерарних вредности - стилистичка анализа далеко је мање заступљена од компаративне. Негативно вреднујући наравоученија уз басне, истичући анегдоте из Собранија... баш зато што су „лепо испричане [...] обично без икаквог указивања на поруку, без досадног 'наравоученија"' (Поповић 1938-39: 136), ${ }^{4}$ Поповић је јасно показао да у Доситејевом делу највише иени његову литерарност, док оно што сматра чистим дидактизмом - иако би се то за наравоученија, нарочито она опширнија, тешко могло прихватити, пре свега због њихове наративне структуре, коју је Поповић сасвим занемарио - види као нешто што смағује вредност том делу. ${ }^{5}$ Због чега, онда, Поповић није дао стилистичку анализу Собранија..., већ је његова монографија имала „за свој главни предмет оцену Собранија и тражење извора дела" (Поповић 1938-39: 75)? Да ствар буде још необичнија, у структури монографије оцена претходи тражењу извора, што значи да од извора не зависи. Отуда, иако је и ту говорио о Лабријеру као Доситејевом извору (Поповић 1938-39: 165), Поповић није поновио оцену из свог ранијег чланка (на који је, међутим, упутио) да Доситеју диже цену већ због саме чињенице што је Доситеј читао и преводио Лабријера. Ако је на крају, дакле, вредност и изворе одвојио, те ако вредност није утврђивао ни стилистички, упркос томе што је стил Собранија ... оно што му је обезбедило средишње место у Поповићевом погледу на Доситеја, на којим је вредносним критеријумима Поповић темељио своју студију-монографију?

Поповић је пошао од питања „која је вредност ових чланака” (Поповић 1938-39: 77) и одговорио да „у своје време они су били одлични, свакако. У њима су ствари тада биле све нове [...] они су били и корисни $[\ldots .$.$] приступачни и врло неуком читаоцу, а пуни благородних мисли, које$

${ }^{4}$ Слично, када је говорио о жанру источњачке приче, Поповић је као њен циљ одредио „све дакле представити у занимљивој и пријатној форми а при том развити коју моралну или философску мисао као поуку. Та је поука казана врло дискретно, као узгред, без непосредног упућивања, без 'наравоученија' које би се досадно наметало читаоцу”' (Поповић 1938-39: 90).

${ }^{5}$ Ово је несагласно средишњем месту које је у Поповићевом пригодном говору приликом откривања Доситејевог споменика добила анализа стила, и у којем је изричито речено да је Доситејев квалитет што је просветитељске идеје нашао начина да представи у оквиру лепе књижевности. То што је у том пригодном чланку јасно видео повезаност литерарности и дидактизма у Доситејевом делу које је у монографији о Собранију... сасвим раздвојио, указује да упркос томе што су пригодни чланци били усмерени на општу оцену у њима могу постојати наговештаји методолошки потенцијално плоднијих приступа, који су међутим остали нереализовани. Колико је, пак, тај пут био плодан, видело се после више од пола века, када се појавила Поетика Доситеја Обрадовића Јована Деретића (1974). 
подижу морал и просвећују друштво” (Поповић 1938-39: 77), али „колико ти чланци вреде данас?/ На жалост, не много. Све што је Доситије у њима рекао, то ми данас знамо одавно, и можда боље" (Поповић 1938-39: 77). Додао је, даље, да „није ни чудо што је тако. Списи ове врсте, или слични, обично застаре чим прође прво време њихова утицаја" (Поповић 1938-39: 77). Поповић је, тако, вредност Доситејевих чланака тражио у актуелности идеја које се у њима излажу, што је знак одсуства историјског перспективизовања, односно одсуства интерпретације: Поповић није Доситејеве чланке тумачио с обзиром на хоризонте њиховог времена и интересе свог, тражећи историјску вредност тих чланака. ${ }^{6}$ Његов приступ био је сасвим неисторијски, нарочито када се упореди са Поповићевим најранијим размишљањима о Доситеју, која су управо почивала на процењивању Доситејевих идеја с обзиром на хоризонт времена у којем су се јавиле (иако те процене нису биле развијене, оне су у својој основној намери биле историјски мотивисане). Уместо тога, у студији-монографији о Собранију... Поповић је признавао да „ипак, има нечега што и данас вреди [...] има понека добра идеја - и данас добра, мислим - и по неки речитији и живописни пасаж, или и цео одељак” (Поповић 1938-39: 78), што значи да је и вредност која је тражена у живописним пасажима, то јест стилу, такође била неисторијска, будући да је Поповићево естетско осећање очигледно било универзалистичко ${ }^{7}$ уосталом, када ни идеје није

${ }^{6}$ Да ли је то изненађујуће, ако је Поповић још у говору „Пред спомеником Доситијевим” супротставио Доситеја као писца који је „и данас млад, свеж, жив, читак” ауторима који „немају за нове генерације него само историјски интерес" (Поповић 1914: 40), очигледно историјско схватајући као нешто што нема никакве везе са актуелношћу, па чак ни вредношћу.

${ }^{7}$ То је у вези са општијом променом у Поповићевом односу према естетици у периоду између „Критике у српској књижевности” и приступног предавања „Проучавање српске књижевности, његови правци и методи”. Иако је у „Критици у српској књижевности” износећи тежњу да „објашњавамо и тумачимо историју литерарних појава у нас” (Поповић 1894: 177) дела процењивао из догматске позиције нормативне поетике, на њих је гледао као на естетски предмет који има своју историчност, те је тим кратким чланком доминирала расправа о разумевању и тумачењу, критика укуса била је у првом плану, док се питања која позитивизам поставља о тексту и биографији писца уопште нису ни помињала. У „Проучавању српске књижевности”, напротив, и естетика ће бити објективизована: „Критика укуса је [...] толико исто научна колико и свака друга. Што она још није дала позитивне научне законе, то је што је наука којој она служи, естетика, тек у зачетку. Кад се по свим областима уметности саберу сви потребни подаци које естетичка критика има да даје; кад се из тих података изведу и одреде услови под којима једно уметничко дело постаје лепо, онда ће и естетика бити тако исто позитивна наука као што су данас природне" (Поповић 1904: 15). Отуда, док је у „Критици у српској књижевности” Поповић покушавао да разуме књижевно дело у његовом историјском контексту, отварајући тиме простор за укрштај естетичке и историјске критике у херменеутици (мада га није остварио), у „Проучавању српске књижевности” естетику ће одредити као позитивну науку, тврдећи да су правила лепога универзална на исти начин на 
сагледавао у историјском контексту њиховог појављивања, било би сасвим неочекивано да је то чинио са стилом дела.

Да ли се, међутим, последицом књижевноисторијског погледа може назвати то што за Поповића „,ланци Собранија имају још једну вредност, друге врсте. Они нам показују духовни развој Доситијев, који је сад друкчији него што је био у доба писања Живота или Басана [...] Само, ако је наш философ и овде претресао старе теме, он их је сада много више развио и лепше изразио./ Али, што је важније, Доситије у Собранију мења теме, оставља старе а узима нове" (Поповић 1938-39: 81) и те разлике међу темама Поповић је педантно бележио? На томе се, међутим, и зауставио. Он није предузео тумачење којим би показао како се Доситејев опус мењао од Живота и прикљученија до Мезимща, већ је остао сконцентрисан само на Собраније..., а све што би његову анализу могло покренути у правцу ширег тумачења смисла Доситејевог опуса није имало интерпретативних последица, иако је баш претпоставка да Собраније... пресудно утиче на тај смисао Поповића навела да о њему тако опширно пише. Рецимо, запажањем да „чудновато је да се [...] код Доситија налази [...] средњевековна легенда, побожна и калуђерска (фратарска); тон и карактер њен сасвим су страни нашем рационалисту и одударају од његових увек модерних мисли; он је, још, узима озбиљно, без подсмеха, и наводи је као пример 'тихо и весело проведеног живота"” (Поповић 1938-39: 87), Поповић је учинио први корак ка интерпретацији, али се на њему и зауставио: уместо да је питањем о могућности такве противречности и специфичности Доситејеве употребе извора ${ }^{8}$ анализирао смисао Доситејеве алегоризације преузете средњовековне легенде, Поповић је остао на нивоу њеног основног смисла, свим варијантама те легенде заједничког, који је за њега био толико саморазумљив да га чак није ни експлицирао.

Одсуство интерпретације нарочито је уочљиво на местима на којима је Поповић анализирао начин на који је Доситеј преводио, односно прилагођавао своје изворе, јер је његов циљ био да покаже само разлике између извора и Доситејевог текста, не и разлоге тих разлика. То што је Доситеј „веома раширио енглески текст. Адисонове речи се ту очевидно налазе, али се ту налази и један велики додатак; тај је додатак, рецимо узгред, сентименталан, и који енглески писац из доба пре Русоа не би никада

који су универзални природни закони, чиме је - парадоксално - била искључена потреба историјске критике коју је заступао.

${ }_{8}^{8}$ „Карактеристично је да је у Доситијевој версији жена (девојка) јунак легенде; обично је, и скоро увек, само човек, и то врло ретко светски човек (путник, младожења) а у великој већини калуђер" (Поповић 1938-39: 87). 
написао" (Поповић 1938-39: 107) изврстан је пример колико је Поповићу стало до тога да покаже разлику, а колико му је мало стало до њених разлога. Иако одлично препознаје сентименталистичко порекло Доситејевог додатка, он га помиње тек „узгред”, не помишљајући да постави питање о сентиментализму као перспективи која управља Доситејевим прилагођавањем извора, иако се сентиментализму на више места враћао: рецимо, „ова идила, којој наравно у енглеском тексту ни трага нема, потпуно је у духу оне сентименталне пасторалне књижевности с краја XVIII века коју је Доситије нарочито волео" (Поповић 1938-39: 109). Немогућност да се постави питање о разлозима Доситејевог мењања извора - а на које је Поповић веома лако могао дати одговор да га је сматрао важним - знак је превласти најчистијег компаративног истраживања (како га је Поповић схватао) и у студији-монографији која је као полазну тачку имала сасвим нов, полемички поглед на целину Доситејевог дела. Зато Поповић нигде није дошао до иүелине Доситејевог портрета, јер он не само што је заобишао сентиментализам као његову битну карактеристику, већ и када је говорио о Доситејевом односу према Сократу, упркос томе што је сматрао да „он је примио целу његову науку о врлини” (Поповић 1938-39: 125), није поставио питање места етичког интелектуализма у Доситејевом делу, баш као што је и Доситејево схватање добродетељног човека као онога који има веру у Бога подједнако далеку и од сујеверја и од зилотизма оценио само као „занимљиво” и ставио у фусноту (Поповић 1938-39: 94ф), не покушавајући да га укључи у тумачење Доситејевог опуса као целине. Не би се могло рећи да Поповић то није чинио зато што су то превасходно филозофске идеје, а он се бавио књижевном анализом; jep, када је Поповић писао да „ових девет [источних] прича доиста потпуно одговарају идејама које је он развијао у чланцима Собранија" (Поповић 1938-39: 92), а у питању су „проста [...] алегорија” (Поповић 1938-39: 92), „поетска новела, [...] визија, [...] шаљива и пријатна старинска прича, [...] философска прича" (Поповић 1938-39: 93), Поповић је показао да је унутар онога што је називао збирним именом „источна прича” веома јасно уочавао жанровске разлике, али их је занемаривао у име идеја изнетих кроз те приче. А ако је то чинио, како је могао да прође поред етичког интелектуализма и питања добродетељи без освртања? Није ли разлог у томе што је Поповић смисао како Доситејевих прилога из Собранија... тако и њихових извора увек видео као јасан и саморазумљив, нешто што не тражи интерпретацију? Ни када је постављао питања која би могла бити права херменеутичка питања - као, на пример, када је осврћући се на Доситејеве типичне теме представљене анегдотама упитао „зашто им дакле 
није посветио чланке, као што је дотле увек чинио" (Поповић 1938-39: 133) - то Поповића није водило ка тумачењу, у случају из примера разлике између чланка и анегдоте, најпре општежанровску, а потом код Доситеја, нити је покушавао да то сагледа с обзиром на целину Собранија..., него је то питање које би могло бити почетак тумачења код Поповића остајало само као реторичко питање, згодан начин да читаоца, у овом случају, уведе у анализирање анегдота.

Одсуство интерпретације, одсуство целовитог погледа на Доситејево Собраније... и, нарочито, његов опус - иако је баш он претпоставка Поповићеве студије-монографије - одређивање вредности с обзиром на актуелност Доситејевих идеја и поука, са једне, и естетске квалитете универзалистички схваћене, са друге стране, тражење извора које није у вези са оценом вредности дела - а што све чини изузетно очигледним и упечатљивим одсуство књижевноисторијске перспективе - доминантно обележава Поповићеву студију-монографију о Собранију... Једину напетост у тај доследан приступ уноси њен завршетак. Започињући други део студије-монографије тврдњом да „други део Собранија - који је издат после смрти Доситијеве 1818. под именом Мезимаи - по духу и врсти продужење је првога, али се од њега у много чему разликује" (Поповић 1938-39: 150), Поповић је - баш као на почетку своје студије разликујући Собраније... од других Доситејевих дела - само побележио разлике између Собранија... и Мезимия, чије је прилоге потом анализирао на исти начин као и оне из Собранија.... Међутим, на завршетку последњег поглавља, посвећеног савременим догађајима у Мезимиу, Поповић је нарочито нагласио „знак новога патриотизма нашег писца, који би био у вези с општим српским патриотским осећањем насталим од устанка Србије...” (Поповић 1938-39: 179): то је ,jедан интиман родољубиви осећај према младој Србији, који он дотле није никад показивао...” (Поповић 1938-39: 180). Занимљиво је да је Поповић, који је ретко користио три тачке, на последње две странице студије-монографије три тачке чак четири пута употребио, и то увек у вези са Доситејевим патриотизмом, српском историјом и Карађорђевом устаничком Србијом. Који је смисао те три тачке? Нису ли оне биле знак отворености питања о Доситејевом патриотизму, потребе да се он сагледа и с обзиром на тренутак писања студије-монографије, уз позив читаоцима да о њему и сами размишљају? У прилог томе говори

једна посебна примедба на крају. Последње речи Мезимияа, које је последње дело нашега просветитеља, гласе овако:

'Остати ће на свету на мерзост и на поруганије један народ који мајсторски пише и говори а неправедно и бесчловечно поступа и твори, који своју реч не держи, и 
веру ломи и гази. Иштимо и таштимо се здрави словесни разум к совершенству доводити, а оно што постигнути не можемо остављајмо времену и управленију Свемогућега'.

Последња од ових двеју реченица казује општу, познату и основну, рационалистичку идеју нашег философа, и она се лепо, свечано завршава побожним тоном убеђеног деиста. Али шта показује она пред њом? Који је то народ на који се овде мисли? (Поповић 1938-39: 180-181).

Тим питањем Павле Поповић је завршио своју студију-монографију о Мезимиу. Упућено читаоцу, оно више не може бити само реторичко, оно мора постати херменеутичко питање, које од читаоца тражи да тумачи Доситејеве речи, али и смисао Поповићевог захтева читаоцу да те речи тумачи, односно смисао отвореног завршетка његове студије-монографије, који је у супротности са остатком те студије-монографије, као и Поповићевим општим маниром писања. Рецимо, баш о националном значају првог чланка Мезимиза,„Јест ли полезно у простом диалекту на штампу што издавати” Поповић је избегао да говори - јер он „више пута је истицан и довољно објашњен. Један од последњих то је учинио Ј. Скерлић, и врло лепо" (Поповић 1938-39: 161) - већ је уместо тога размишљао о мотивима које је Доситеј могао имати да тај чланак напише. Колико год ти мотиви били битни као друштвени и културни контекст интерпретације, они сами не могу заменити интерпретацију. Ако Поповићу кроз целу студију-монографију није било стало до интерпретације него се задовољавао уобичајеним представама о смислу Доситејевих дела, баш то чини његов завршетак, његову отвореност која призива интерпретацију, тако необичним. Ту необичност посебно наглашава на крају последњег поглавља први пут присутна тежња да се покаже Доситејева промена, али не само у темама или стилу, већ егзистеничиална промена, која оставља последице на целовиту представу о Доситеју.

Међутим, Доситејев заокружени портрет Поповић ипак није дао. Управо је зато то позно инсистирање на Доситејевом позном и новом родољубљу тако необично, нарочито ако се узме у обзир да је Поповић морао бити свестан да то инсистирање није ни сасвим тачно, јер је одавно знао да „када је био студент на Университету у Лајпцигу уписао се је под именом 'Доситеј Обрадовић из Србије”' (Поповић 1919: 54), а што такође, можда чак и више, говори о Доситејевом патриотизму (уп. Ломпар 2002). ${ }^{9}$ Завршетак студије-монографије о Собранију... и његовом другом

\footnotetext{
${ }^{9}$ Као што сам показао у студији „Доситеј, Србија и Камчатка или О просвећеном национализму" (Николић 2008) за Доситејево родољубље је, када је реч о његовим позним годинама, важнија била спремност да напусти устаничку Србију ако се у њој не уведе штампарија; спремношћу да поново крене у свет вођен страшћу књигоиздавања, односно жељом
} 
делу Мезимиу зато уноси напетост у њу: Доситејев портрет, о којем се до тада водило мало рачуна, добија једну нову црту која је нарочито тражена, да преко идеје о српском родољубљу припреми завршну напомену која призива интерпретацију не само Доситејевих речи, већ и положаја српског народа уопште; притом, та црта није она због које је на почетку студије-монографије Поповић тврдио да без Собранија... Доситеј за њега не би имао толико привлачности. Завршетак је, дакле, донео савремену заинтересованост за Доситејево дело, за корист од њега у садашњости, и то другачију него раније, како с обзиром на одбацивање актуелности Доситејевих идеја у студији-монографији, тако и с обзиром на Поповићеву ранију политичку злоупотребу Доситеја, када је његово место у савремености Срба, Хрвата и Словенаца сасвим другачије одређивао. У чланку „Утицај непосредних и одложених последица Првог светског рата на књижевноисторијски опис и оцену Доситеја Обрадовића у књижевној историји Павла Поповића" (Николић 2015) детаљно сам показао како је Поповић у Југословенској књижевности (1918) свесно кривотворио Доситејеве речи да би се Доситеј појавио као пропагатор југословенског јединства, да би са променом политичких околности у Краљевини Југославији - за које је преломан тренутак био атентат на краља Александра 1934. године - Поповић управо у студији-монографији о Собранију... имплицитном полемиком са својом некадашњом злоупотребом Доситеја у југословенске сврхе истинито представио Доситеја као пропагатора српског јединства. Води ли нас то запажање ближе смислу Поповићевог херменеутичког питања са завршетка студије-монографије о Собранију..., уочавањем да оно није постављено само с обзиром на Доситејеве идеје, него на Поповићев промењен однос према југословенској идеји, који је морао пратити и другачији однос према Доситеју, који је од првог пропагатора југословенског јединства поново за Поповића постао српски родољуб? Ако је код Поповића југословенска политика била „тако постављена да онемогућава књижевноисторијску интерпретацију” (Николић 2015: 461), одустајање од те политике - које је и само политично - није довело до књижевноисторијске интерпретације, којој Поповић у својој студији-монографији уопште није био склон, него до отвореног завршетка који свој херменеутички потенцијал прелива ка читаоцу. Док је током целе

да своју љубав за Србе настави да испољава преносећи им и даље мудре и корисне мисли, а не тек тако боравећи међу њима, без штампарије лишен могућности да их књигама васпитава, Доситеј је дао пример просвећеног национализма као задатка „да бринући о добробити својих ближњих стварамо заједницу која ће бити место напредовања и самоостварења сваког од нас" (Николић 2008: 106). 
своје студије-монографије Поповић показивао да су Доситејеве идеје по правилу превазиђене и да се тек ту и тамо може наћи нека која би још увек вредела непосредно примењена, на њеном завршетку учинио је скок у интерпретацију, постављајући питање шта Доситеј значајно може рећи његовим савременицима, али не на нивоу саморазумљивог значења његових речи, већ размишљањем о њима с обзиром на хоризонт Доситејевог времена, светскоисторијске промене из тог доба и Доситејеву егзистенцијалну промену која се кроз те речи оспољила. Тај скок у интерпретацију био је, међутим, намењен другима, јер би студија која би желела да буде интерпретативна морала бити сасвим другачија од Поповићеве студијемонографије: уместо широка по обиму предмета испитивања а уска по приступу том предмету, она би морала бити усмерена на она места којима Доситеј нешто говори савременим читаочима, али - вреди поновити - не у смислу у којем је Поповић неке његове идеје карактерисао као и данас корисне, лепе, пријатне и слично, него управо у оном смислу на који је апеловало његово последње питање, егзистенцијалном смислу афицираности Доситејевим речима као мостом између једног прошлог и садашњег доба, оба изузетно немирна и неизвесна. Међутим, изузетност тог питања сведочи да је оно надилазило заинтересованост за Доситеја и да је постављено са општијег хоризонта промене Поповићевог односа према југословенској идеји: управо отклоном од сопствене некадашње политичке злоупотребе Доситеја, Поповић је своју студију-монографију учинио изузетно политичном, а питање којим ју је завршио испоставља се као пре свега питање о времену које долази и чије тешке последице сам Поповић неће доживети.

Јер, сама заинтересованост за Доситејеву егзистенцијалну ситуацију, ретка, није доводила до херменеутичких питања, нарочито не таквих која би захтевала радикално мењање општеприхваћене представе о Доситеју. Иако је Поповић о Собранију... писао у полемичком отклону од традиције тумачења, са жељом да покаже да би Доситеј сасвим другачије изгледао без тог дела, дакле тражећи корекцију и опште представе о Доситеју, он је то што у Собранију... ,јако пада у очи [...] местимично песимистично расположење, мисли црне, нешто горчине или резигнације, што пре као да није показивао” (Поповић 1938-39: 82) образложио као „старачко искуство. У основи он је оно што је целога века био, оптимист” (Поповић 1938-39: 82). Заобилажење питања о могућности песимизма у делу изразитог оптимисте као што је Доситеј, осим што поново указује на одсуство интерпретације, такође открива и снагу културе која Поповића онемогућава да уопште мисли о Доситејевом песимизму, због чега га 
је и склонио у страну тврдњом да је последица „старачког искуства”, дакле нешто антрополошко, ствар његових година, а никако у самој Доситејевој мисли засновано. Можда заиста и јесте тако, али је то требало показати - овде је зато најиндикативније Поповићево одустајање да се тим питањем озбиљно бави, због чега иако је превредновао Доситејево дело, он је то превредновање задржао у оквирима најопштијег културног консензуса, због чега је оно пре преакиентовање него право превредновање. Уосталом, и само вредновање Доситејевог дела било је недовољно кохерентно, а нису доследно поштовани ни различити критеријуми вредновања који су наизменично примењивани: актуелност, естетика, место у развоју. Парадоксално је да је у кратким чланцима, као рецимо „Пред спомеником Доситијевим”, вредновање било доследније изведено - ту је вредност тражена у Доситејевој литерарности, па је показано преко којих стилских и жанровских особина његовог дела „Доситије, који је у основи идеолог и апстрактни мислилац, представља у исто доба и писца велике занимљивости и нарочитих лепота" (Поповић 1914: 41). Могуће је замислити студију за коју би тај чланак представљао сиже, и та би студија свакако била кохерентнија од студије-монографије о Собранију... Она је, међутим, свакако специфична по прикривеној тежњи да испод великог броја података о Доситејевим изворима оповргне Поповићеву југословенску злоупотребу Доситеја, која је практично неприметна све док се студија-монографија не прочита у контексту свега што је Поповић писао о Доситеју - не само у чланцима њему посвећеним - а која када се препозна указује и на хоризонт са којег је могла бити написана последња реченица, херменеутичко питање упућено читаоцу.

У писању Павла Поповића о Доситеју Обрадовићу препознају се тако три важна, преломна момента: први, између 1894. и 1904. када је постепено напуштао скепсу према Доситеју с обзиром на његову критику манастира, затим после 1918. када је Доситејеве речи кривотворио како би у њему препознао првог прокламатора југословенског јединства, те на крају после убиства краља Александра 1934. када је у студији-монографији о Собранију... управо Доситејеве речи које је био кривотворио нагласио као речи које захтевају јединство српског народа, како је код Доситеја и било. Иако је практично све што је Поповић писао о Доситеју после ступања на катедру Велике школе (која ће годину дана касније прерасти у Универзитет) представљало оповргавање његове младалачке критике Доситеја, као да је она, ипак, све време стајала уз Поповићево писање о Доситеју као сенка, те отуда и потреба да се још и 1934. непотребним наглашавањем ваздашње и непромењене одушевљености за Доситеја 
опорекну своје младалачке сумње. Колико ли је онда теже морало бити живети са кривотворењем Доситејевих речи у име југословенске идеје, нарочито онда када је постало сасвим јасно да од те идеје није остало ништа? Олакшавши своју душу у студији-монографији истинитим представљањем Доситејевог патриотизма, Поповић је њен други део - у години успостављања Бановине Хрватске - завршио позивом читаоцима да мисле о Доситејевом родољубљу, али и о томе који је то један народ „који мајсторски пише и говори а неправедно и бесчловечно поступа и твори, који своју реч не держи, и веру ломи и гази”. Ове мене у односу Павла Поповића према Доситеју најмање су имале везе са књижевноисторијским испитивањима; чак би се могло рећи да су она - нарочито компаративна, која нису улазила у разлоге Доситејевих преузимања и преиначавања грађе Собранија ... - заклањала дубљу везаност Павла Поповића за Доситеја коме се враћао читавог живота: да се са њим спори, да му импонује личношћу, да пристане уз његове идеје и иде за њим, да га изда и кривотвори, да му се на крају врати као српском родољубу. Садржајем и дометима за проучавање Доситеја Обрадовића не превише важни, чланци и студије Павла Поповића изузетно су сведочанство вишеструких духовних прекретања у четири и по деценије његовог јавног деловања. За разлику од Доситеја чије је једино прекретање било колико одлучно толико и неопозиво, како за њега самога, тако и за српску културу којој је дало нови ритам (Грбић 2012: 19), Поповићеви преокрети обележени су напуштањима и враћањима, променама у којима је превелику улогу имала политика. Живећи идеју просвећености, Доситеј је своје прекретање учинио неповратним, док је Поповићева променљивост одражавала промене политике која је њим управљала. Вођен политиком, уз методологију која је спутавала интерпретацију, Поповић није могао, осим ободно, узгредно, из своје интуиције и искреног осећаја, да буде на висини Доситејевог дела. Због тога су његове компаративне студије пуне података, тачних али са мало смисла, док се у појединим успутним опаскама препознаје потенцијално богатство једне могуће, другачије мисли о Доситеју Обрадовићу, чију целину - како личности, тако и дела - Павле Поповић није могао сагледати.

\section{ЛИТЕРАТУРА}

Грбић 2012: Драгана Грбић. Прекретања. Хале - Лајпииг, прекретница у животу Доситеја Обрадовића / D. Grbić, Vorentscheidungen. Halle - Leipzig, Wendepunkt im Leben von Dositej Obradović, Превод и редакција превода на немачки А. Рихтер / Übersetzung ins Deutsche und Redaktion der 
Übersetzung A. Richter. Halle - Београд: Seminar für Slavistik der MartinLuther-Universität Halle-Wittenberg, Институт за књижевност и уметност, Interdisziplinäres Zentrum für die Erforschung der Europäischen Aufklärung der Martin-Luther-Universität Halle-Wittenberg.

Деретић 1974: Ј. Деретић, Поетика Доситеја Обрадовића, Београд: „Вук Караџић”. (прештампано уз измене као Поетика просвећивања: књижевност и наука у делу Доситеја Обрадовића, Београд: Књижевне новине, 1989).

Костић 1952: М. Костић, Доситеј Обрадовић у историској перспективи XVIII и XIX века, Београд: Српска академија наука.

Ломпар 2002: М. Ломпар, Етида за Јована Деретића, Летопис Матиие српске, год. 178, књ. 469, св. 6, јун 2002, Нови Сад, 899-900. (прештампано у незнатно измењеном облику и под насловом „Доситеј”, у: М. Ломпар, Моралистички фрагменти, Београд: Народна књига, 2007, 85-87; друго, проширено издање, Београд: Нолит, 2009, 75-77).

Николић 2008: Н. Николић, Доситеј, Србија и Камчатка или О просвећеном национализму, у: Меандри просвећености: Неколико лица српске књиюеевности XVIII и XIX века, Београд: Службени гласник, 2010, 89-106.

Николић 2015: Н. Николић, Утицај непосредних и одложених последица Првог светског рата на књижевноисторијски опис и оцену Доситеја Обрадовића у књижевној историји Павла Поповића, у: Први светски рат и српска књижевност. Два века од Вукове „Мале простонародне славеносрпске пјеснарице", Научни састанак слависта у Вукове дане, 44/2, Београд: Међународни славистички центар, 2015, 457-462.

Остојић 1907: Т. Остојић, Доситеј Обрадовић у Хопову: студија из културне и књижевне историје. Нови Сад: Матица српска, [фототипско издање: Нови Сад: Матица српска, 2002].

Поповић 1894: П. Поповић, Критика у српској књижевности, у: Књижевна критика - Кюижевна историографија, (пр.) Мирослав Пантић (Сабрана дела Павла Поповића, књ. 10), Београд: Завод за уџбенике и наставна средства, 2002, 177-183.

Поповић 1897: П. Поповић, Једна погрешка Доситијева, у: Кюижевна критика - Кьижевна историографија, (пр.) М. Пантић (Сабрана дела Павла Поповића, књ. 10), Београд: Завод за уџбенике и наставна средства, 2002, 405-406.

Поповић 1903: П. Поповић: Матија Бан и његов књижевни рад у Дубровнику, у: Дубровачке студије, (пр.) Злата Бојовић (Сабрана дела Павла Поповића, књ. 4), Београд: Завод за уџбенике и наставна средства, 2000, 432-441 
Поповић 1904: П. Поповић, Проучавање српске књижевности, његови правци и методи, у: Кюижевна критика - Кюижевна историографија, (пр.) Мирослав Пантић (Сабрана дела Павла Поповића, књ. 10), Београд: Завод за уџбенике и наставна средства, 2002, 5-37.

Поповић 1911: П. Поповић, Доситеј и Лабријер, у: Нова књижевност I: Од Доситеја до Вука и Стерије, (пр.) П. Палавестра (Сабрана дела Павла Поповића, књ. 5), Београд: Завод за уџбенике и наставна средства, 2000, 37-39.

Поповић 1914: П. Поповић, Пред спомеником Доситијевим [Говор држан приликом откривања споменика Доситију Обрадовићу], у: Нова књижевност I: Од Доситеја до Вука и Стерије, пр. Предраг Палавестра (Сабрана дела Павла Поповића, књ. 5), Београд: Завод за уџбенике и наставна средства, 2000, 40-42.

Поповић 1919: П. Поповић, Доситеј Обрадовић у Енглеској [Предавање држано у King's College-у у Лондону 19. фебруара 1918. г.], у: превео Владимир М. Вукмировић, Нова књижевност I: Од Доситеја до Вука и Стерије, пр. Предраг Палавестра (Сабрана дела Павла Поповића, књ. 5), Београд: Завод за уџбенике и наставна средства, 2000, 43-56.

Поповић 1927: П. Поповић, Фрањевци у нашој књижевности, науци, уметности [Говор држан на свечаности поводом седамстогодишњице Св. Фрање, 7. децембра 1926. у Београду], у: Дубровачке студије, пр. Злата Бојовић (Сабрана дела Павла Поповића, књ. 4), Београд: Завод за уџбенике и наставна средства, 2000, 142-146.

Поповић 1932: П. Поповић, Јован Н. Томић и архивски рад, у: Къижевна критика - Кьижевна историографија, пр. М. Пантић (Сабрана дела Павла Поповића, књ. 10), Београд: Завод за уџбенике и наставна средства, 2002, 125-134.

Поповић 1934: П. Поповић, Доситије Обрадовић. Поводом сто педесете годишњице његове прве књиге, у: Нова кьижевност I: Од Доситеја до Вука и Стерије, пр. П. Палавестра (Сабрана дела Павла Поповића, књ. 5), Београд: Завод за уџбенике и наставна средства, 2000, 186-189.

Поповић 1938-39: П. Поповић, О Собранију Доситија Обрадовића (I део 1938, II део 1939), у: Нова књижевност I: Од Доситеја до Вука и Стерије, (пр.) П. Палавестра (Сабрана дела Павла Поповића, књ. 5), Београд: Завод за уџбенике и наставна средства, 2000, 69-181.

Поповић 2001: П. Поповић, Из дневника, (пр.) Б. Љ. Поповић (Сабрана дела Павла Поповића, књ. 11), Београд: Завод за уџбенике и наставна средства. 
Фројд 1925: S. Freud, Oporicanje (Die Verneinung), y: Đavolja neuroza: izabrani ogledi, izabrao i preveo J. Aćin, Beograd: Rad, 2001, 112-116.

Nenad V. Nikolić

\section{PAVLE POPOVIĆ ON DOSITEJ OBRADOVIĆ}

\section{Summary}

The paper discusses Pavle Popović's articles and studies focused on the works of Dositej Obradović. They demonstrate several different ideological and methodological threads: the youthful condemnation of Dositej Obradović for his critique of the monasteries, the emphasis on Dositej as the founder of modern Serbian literature and a still current author, and the thourough comparative study of The Collection of Various Moral Matters and The Darling (Mezimac). These threads are viewed in the context of Popović's more general methodological, literary-historical and political considerations.

Key words: The Darling, Dositej Obradović, Pavle Popović, The Collection of Various Moral Matters 